\title{
Decomposed Babassu Biomass: New Substrate for the Production of Jacaranda mimosifolia D. Don Seedlings
}

\author{
Henrique Simões Cavalcante ${ }^{1}$ \\ Pedro Victor Santos de Sousa ${ }^{1}$ \\ Raimundo José Nascimento dos Santos ${ }^{1}$ \\ Kleber Veras Cordeiro ${ }^{1}$ \\ Hosana Aguiar Freitas de Andrade ${ }^{2}$ (i) \\ Nitalo André Farias Machado ${ }^{2}$ \\ Raissa Rachel Salustriano da Silva-Matos ${ }^{1}$
}

\begin{abstract}
In Maranhão babassu forest, the decomposed babassu biomass (DBB) has been used empirically by several farmers for the production of Jacaranda mimosifolia seedlings. This study aimed to evaluate the potential of DBB as a substrate. The substrate compositions were S1: 100\% soil (control); S2: 20\% DBB; S3: 40\% DBB; S4: 60\% DBB; S5: 80\% DBB and S6: 100\% DBB. The experiment was carried out from October to December 2019 at Federal University of Maranhão, Chapadinha, Maranhão, Brazil. It was observed the use of DBB enhances the emergency speed index and germination percentage, besides resulted in the development of the aerial part and the root development. Thus, DBB may be used as an alternative substrate for the production of Jacaranda mimosifolia seedlings. It is recommended to include $40 \%$ babassu biomass with $60 \%$ soil in the composition of the substrate to improve the morphological development of Jacaranda mimosifolia seedlings.
\end{abstract}

Keywords: Alternative Substrates, Attalea speciosa Mart, Seedling Quality, Sustainability.

\section{INTRODUCTION}

In Brazil, the population's awareness of environmental problems boosted the demand for native forest seedlings for reforestation and recovery of deforested areas, allowing efficient recovery of vegetation cover, essential for the restoration of environmental balance (Gonçalves et al., 2015; Soares et al., 2017; Freitas et al., 2017).

Among the forest species with the potential to be used in reforestation projects, Jacaranda mimosifolia D. Don stands out, a tree native to Brazil, belonging to the Bignoniaceae family (Zaghloul et al. 2011). This tree is widely distributed in tropical and subtropical regions of the world (Moharram \& Marzouk 2007). Furthermore, it is used in urban afforestation and as an ornamental plant (Socolowski \& Takaki, 2004).
However, one of the main problems encountered in the formation of stands aiming the forest restoration is the quality of seedlings (Lima Filho et al., 2019). Good quality seedlings are essential in the development of forest populations, as they present higher resistance to biological and abiotic conditions, directly implying in the success of these forest areas (Cruz et al., 2004; Dionísio et al., 2019). The production of quality forest seedlings is conditioned to the substrate used during leading and management since seed germination and the initial development of species are linked to the particularities of each substrate (Caldeira et al., 2012).

In the exposed, the use of organic materials in the substrate composition held an excellent alternative for the use of residues, as well as the source of plant nutrients that might reduce the high costs to the minimum necessary for the production of forest seedlings (Trazzi et al., 2013).

\footnotetext{
${ }^{1}$ Universidade Federal do Maranhão, Chapadinha, MA, Brasil
}

${ }^{2}$ Universidade Federal do Ceará, Fortaleza, CE, Brasil 
In that context, in the transition zone among Amazon, Cerrado, and Caatinga biomes, the decomposed babassu biomass (DBB) has been used empirically by several farmers for seedlings production. Babassu biomass is an organic residue to be obtained after the process of decomposition of the babassu palm (Attalea speciosa Mart.).

Therefore, the objective was to analyze the potential use of decomposed babassu biomass in the production of Jacaranda mimosifolia seedlings.

\section{MATERIAL AND METHODS}

\subsection{Location}

The experiment was carried out from October to December 2019 at the Center for Agricultural and Environmental Sciences at the Federal University of Maranhão, Chapadinha, Maranhão, Brazil ( $3^{\circ} 44^{\prime} 12.62^{\prime \prime}$ S, $43^{\circ} 19^{\prime} 03.51^{\prime \prime} \mathrm{E}$, and 105 meters above sea level). The climate classification of the region is humid tropical, with an average annual rainfall of $1613.2 \mathrm{~mm}$ and a mean annual temperature of $26.9^{\circ} \mathrm{C}$ (Passos et al., 2016).

\subsection{Experimental design and treatments}

The study was carried out in a completely randomized design, with six treatments, that is, six substrate compositions having as a component, the babassu decomposed biomass (DBB) residue, arranged in 5 repetitions, each containing five plants, totaling 25 plants per treatment and 150 in the total. The substrate compositions were: S1: $100 \%$ soil + 0\% DBB (control); S2: $80 \%$ solo + 20\% DBB; S3: $60 \%$ solo $+40 \%$ DBB; S4: $40 \%$ solo $+60 \%$ DBB; S5: $20 \%$ solo $+80 \%$ DBB and S6: $0 \%$ solo $+100 \%$ DBB.

$\mathrm{DBB}$ was provided through the association of rural products from Chapadinha-MA. The soil collected in the experimental area of the Federal University of Maranhão was classified as dystrophic Yellow Latosol (Santos et al., 2013), composed of 560,190 , and $250 \mathrm{~g} \mathrm{Kg}-1$ of sand, silt, and clay, respectively, had an "average" textural classification. The granulometric analysis was performed as proposed by Almeida et al. (2012).

\subsection{Physical and chemical characterization of substrates}

The samples of substrate compositions were sent to the Soil Science Laboratory at the Federal University of Ceará, Fortaleza, Brazil, to determine the global density (GD), particle density (PD), and total porosity according to the procedures described by Brazilian Agricultural Research Corporation (EMBRAPA, 1997).
To GD determination (Table 1), samples were inserted in a volumetric ring of known volume and then placed in an oven with forced air circulation at $105^{\circ} \mathrm{C}$ for 24 hours (SS ${ }^{\circledR}$, MBSSDCR40L, São Paulo, SP, Brazil). Thus, GD was determined by the relationship between sample volume and weight (Table 1). After drying in an oven at $105^{\circ} \mathrm{C}$ for 24 hours, the samples were transferred to a $50 \mathrm{~mL}$ volumetric flask containing ethyl alcohol, where it was possible to determine the $\mathrm{PD}$ and porosity by equations 1 and 2 , respectively.

$$
P D=\frac{\mathrm{KSW}}{50-\mathrm{V}}
$$

$$
\text { Porosity }=1-\frac{\mathrm{GD}}{\mathrm{PD}}
$$

In which: PD: particle density $\left(\mathrm{g} \mathrm{cm}^{-3}\right)$; GD: global density $\left(\mathrm{g} \mathrm{cm}^{-3}\right)$; KSW: kilndried sample weight (g); V: volume of alcohol $\left(\mathrm{cm}^{3}\right)$.

Table 1. Physical characterization: global density (GD), particle density (PD), and total porosity.

\begin{tabular}{cccc|} 
& GD & PD & Porosity \\
\cline { 2 - 4 } Substrates & & $\left(\mathrm{g} \mathrm{cm}^{-3}\right)$ & \\
S1 & 1.44 & 2.67 & 45.99 \\
S2 & 1.28 & 2.64 & 51.53 \\
S3 & 1.18 & 2.57 & 54.01 \\
S4 & 0.98 & 2.24 & 56.22 \\
S5 & 0.73 & 1.88 & 60.91 \\
S6 & 0.33 & 0.97 & 65.95 \\
\hline
\end{tabular}

S1: $100 \%$ soil + 0\% DBB (control); S2: $80 \%$ soil + $20 \%$ DBB; S3: $60 \%$ soil + 40\% DBB; S4: $40 \%$ soil $+60 \%$ DBB; S5: $20 \%$ soil $+80 \%$ DBB, and S6: $0 \%$ soil $+100 \%$ DBB.

The $\mathrm{pH}$ values, electrical conductivity, nitrogen, phosphorus, potassium, calcium, magnesium, and sulfur of the compositions of each substrate were determined by the methodology described in Normative Instruction No. 17 of the Ministry of Agriculture, Livestock, and Supply of Brazil (MAPA, 2007) (Table 2).

$\mathrm{pH}$ of each substrate was determined by direct measurement in a solution of the substrate with water in the proportion 1:2.5 using a pH meter (Simpla ${ }^{\oplus}$, PH140, São Caetano, SP, Brazil). EC was determined by direct electrode reading using a conductivity meter (CDH222, São Caetano, SP, Brazil) after obtaining the soil solution by the method of paste saturation with vacuum extraction.

The nitrogen content was determined by applying a method adapted from Kjeldahl, with digestion in $\mathrm{H}_{2} \mathrm{SO}_{4}$ followed by steam distillation with $\mathrm{NaOH}$ solution, and also, an $\mathrm{H}_{3} \mathrm{BO}_{3}$ solution as an indicator. After distillation, titration was performed 
with a standard $\mathrm{HCl}$ solution. The carbon was analyzed by the Walkley-Black method, using samples dried at $65^{\circ} \mathrm{C}$. The calcium and magnesium contents were determined by atomic absorption spectrometry (Konica Minolta ${ }^{\circ}, \mathrm{CM}-3600 \mathrm{~A}$, Tokyo, Japan) after extraction with $1 \mathrm{~mol} \mathrm{~L}^{-1} \mathrm{KCl}$. The potassium content were determined using a flame photometer (Digimed ${ }^{\circ}$, DM-63, São Paulo, SP, Brazil) and the phosphorus and sulfur contents were obtained with a photocolorimeter (Alfakit ${ }^{\circ}$, AT 100P II, Florianópolis, SC, Brazil) after extraction with Melich 1 solution $\left(\mathrm{HCl} 0,05 \mathrm{~mol} \mathrm{~L}^{-1}+\mathrm{H}_{2} \mathrm{SO}_{4} 0.0125 \mathrm{~mol} \mathrm{~L}^{-1}\right)$.

Table 2. Chemical characterization: hydrogen potential $(\mathrm{pH})$, electric conductivity $(\mathrm{EC})$, nitrogen $(\mathrm{N})$, carbon $(\mathrm{C})$, phosphorus $(\mathrm{P})$, potassium $(\mathrm{K})$, calcium $(\mathrm{Ca})$, magnesium $(\mathrm{Mg})$, and sulfur $(\mathrm{S})$.

\begin{tabular}{|c|c|c|c|c|c|c|c|c|c|}
\hline \multirow{2}{*}{ Substrates } & $\mathbf{p H}$ & EC & $\mathbf{N}$ & C & $\mathbf{P}$ & K & $\mathrm{Ca}$ & Mg & $\mathbf{S}$ \\
\hline & & $\mathrm{dS} \mathrm{m}^{-1}$ & \multicolumn{2}{|c|}{$\mathrm{g} \mathrm{kg}^{-1}$} & $\mathrm{mg} \mathrm{kg}^{-1}$ & \multicolumn{4}{|c|}{$\mathrm{cmol}_{\mathrm{c}} \mathrm{kg}^{-1}$} \\
\hline S1 & 5.06 & 0.10 & 0.63 & 8.94 & 13.00 & 0.07 & 0.80 & 0.30 & 1.50 \\
\hline S2 & 4.88 & 0.61 & 1.23 & 14.76 & 14.00 & 0.67 & 1.60 & 1.00 & 3.80 \\
\hline S3 & 5.11 & 1.36 & 1.46 & 21.48 & 13.00 & 1.82 & 3.20 & 1.70 & 7.60 \\
\hline S4 & 4.83 & 1.79 & 2.02 & 40.92 & 13.00 & 2.35 & 4.40 & 2.80 & 10.80 \\
\hline S5 & 5.16 & 3.00 & 3.47 & 44.04 & 27.00 & 6.17 & 10.90 & 4.60 & 24.60 \\
\hline S6 & 5.32 & 4.34 & 5.88 & 145.20 & 33.00 & 3.63 & 20.60 & 15.20 & 41.50 \\
\hline
\end{tabular}

S1: $100 \%$ soil + 0\% DBB (control); S2: 80\% soil + 20\% DBB; S3: 60\% soil + 40\% DBB; S4: 40\% soil + 60\% DBB; S5: 20\% soil + 80\% DBB, and S6: 0\% soil + 100\% DBB.

\subsection{Experimental procedure}

The seeds were obtained from four Jacaranda mimosifolia trees in the municipality of Anapurus, Maranhão, Brazil. Seeds were sown in polyethylene bags $(12 \times 20 \mathrm{~cm})$ with two seeds per bag at $1-\mathrm{cm}$ depth. The bags were placed on a wooden bench in an area covered by Sombrite ${ }^{\bullet}$ with $70 \%$ shading. On average, each seedling received $\sim 0.25 \mathrm{~L}$ of water per day in the late afternoon during the experiment, using a $5 \mathrm{~L}$ capacity manual watering can.

Phytosanitary control was carried out according to the technical recommendations adopted in the region for the crop, with preventive applications of the organic insecticide Neem oil (Azadirachta indica) at the dose of $10 \mathrm{~L} \mathrm{ha}^{-1}$ weekly during the experiment. There was daily monitoring to investigate phytosanitary issues of the seedlings, and no damage was identified throughout the research.

Two days after sowing (DAS), seeds started emerging with fully open cotyledons above the substrate while at 23 DAS, seedlings were thinned, which only one plant per bag was left. The germination percentage (GP) and emergency speed index (ESI) were calculated based on these data, according to Silva Matos et al., (2015). At 60 DAS, seedling height ( $\mathrm{SH}$ ), (measured from the lap to the insertion of the last leaf), root length (RL), diameter at neck height (lap) $(\mathrm{DNH})$, root volume (RV), aboveground dry mass (ADM), belowground dry mass (BDM).
The leaf area (LA) was obtained through the photographic record of the leaf and subsequent digitized image analysis with the aid of the Image $\mathrm{J}^{\circledR}$ software. For the height and length measurements, graduated rulers in mm were used. Besides, for the diameter, a digital caliper (100.174BL, Digimess ${ }^{\oplus}$, São Paulo, SP, Brazil) was employed. RV was recorded by measuring the water column displacement in a graduated beaker promoted by roots, having a known volume of water $(100 \mathrm{~mL})$. Moreover, to determine ADM and BDM, fresh material was placed in a forced-air-circulation oven for $72 \mathrm{~h}$ and then weighed on a precision scale (AD5002, Dubesser ${ }^{\circ}$, São Caetano do Sul, SP, Brazil). The Dickson quality index (DQI) was determined according to Equation 3 (Dickson et al., 1960).

$$
\mathrm{DQI}=\mathrm{TDM} /(\mathrm{HP} / \mathrm{DSD}+\mathrm{ADM} / \mathrm{BDM})
$$

In which: $\mathrm{TDM}=$ total dry mass $(\mathrm{g}) ; \mathrm{HP}=$ plant height $(\mathrm{cm}) ; \mathrm{SD}=$ stem diameter $(\mathrm{cm}) ; \mathrm{ADM}=$ aboveground dry mass $(\mathrm{g}) ; \mathrm{BDM}=$ belowground dry mass $(\mathrm{g})$.

\subsection{Statistical analysis}

Analyses were made using Infostat 2020 (Di Rienzo et al., 2020). In the present study, $\mathrm{P}<0.05$ was set as statistical significance for all tests. Data were submitted to normality analysis by the Shapiro Wilk test. GP and ESI were submitted to analysis of variance (ANOVA), followed by a Tukey test. Moreover, other variables, when significant, were explored by regression analysis. Associations among variables were 
assessed using Pearson's linear correlation coefficient (r), as shown in Equation 4.

$$
\mathrm{r}=\frac{1}{\mathrm{n}-1} \sum_{i=1}^{\mathrm{n}}\left(\frac{\mathrm{xi}-\overline{\mathrm{x}}}{\mathrm{Sx}}\right) \cdot\left(\frac{\mathrm{yi}-\mathrm{y}}{\mathrm{Sy}}\right)
$$

In which $\mathrm{x}$ and $\mathrm{y}$ are the sample means of $\mathrm{x}$ and $\mathrm{y}$, respectively, and $\mathrm{Sx}$ and Sy are the sample standard deviations of $\mathrm{x}$ and $\mathrm{y}$, respectively.

\section{RESULTS AND DISCUSSION}

The use of DBB resulted in the development of the aerial part of the Jacaranda seedlings, with effect for LA $(\mathrm{P}<0.001)$, $\mathrm{SH}(\mathrm{P}=0.005), \mathrm{DNH}(\mathrm{P}=0.003)$. In addition, it resulted in an effect for ESI ( $\mathrm{P}=0.002)$, GP $(\mathrm{P}<0.001)$ and IDQ $(\mathrm{P}=0.043)$. However, it did not change the root development of the seedlings, except for BDM $(\mathrm{P}=0.046)$ (Table 3$)$.

The substrates formulated with 20 to $80 \% \mathrm{DBB}$, promoted a better emergence speed index (ESI), with an average of 4.55 . While control (100\% soil $+0 \% \mathrm{DBB})$, and substrates with $100 \%$ DBB reduced the ESI by 23.51 and $45.71 \%$, respectively (Figure 1A). The substrate composed of $80 \%$ DBB increased $(\mathrm{P}<0.05)$ the percentage of germination of the seeds, obtaining $98.75 \%$ of the seeds germinated (Figure 1B). This occurs due to the structure and capacity of aeration and water retention of the substrates analyzed in these DBB properties, since these characteristics influence the water absorption rate and the biochemical reactions related to germination (Martins et al., 2013; Oliveira et al., 2015). Therefore, compositions of 20 to $80 \%$ of DBB promoted a more favorable environment for germination.

S1 (control), was characterized by presenting low porosity, and this may have resulted in an inadequate supply of oxygen in the tissues (Barreto et al., 2018), in addition to less nutritional capacity, although at this time this characteristic is not one of the most limiting. On the other hand, the inclusion of $\mathrm{DBB}$, in the substrates provided an increase in the porosity characteristic, positively altering the performance of ESI and the germination of Jacaranda seedlings. However, in S6 $(0 \%$ soil $+100 \% \mathrm{DBB})$, due to the high porosity and the lower water retention capacity, and consequently, less water content available for the seeds, they provided lower mean SDI and germination values $(\mathrm{P}<0.05)$, than the control substrate (S1), Table 1.

Therefore, seed germination improved from a increase in DBB in the composition of the substrates, possibly according to the adequate supply ratio between water and oxygen. Han et al., (2018) evaluated the germination of Picea jezoensis seedlings and found the highest germination percentage (50\%) in substrates with woody debris concerning the soil (28\%) and sand $(28 \%)$ due to porosity characteristics, similar to that observed in this study.

The responses of $\mathrm{BDM}, \mathrm{LA}, \mathrm{SH}$, and $\mathrm{DNH}$ were adjusted in quadratic polynomial models with $\mathrm{R}^{2}=0.709 ; 0.755 ; 0.723$; and 0.656 , respectively. The highest values were obtained in the substrates with 40 to $80 \%$ DBB (Figure 2).

These positive responses to the morphological attributes with the inclusion of DBB in the soil are possibly related to the fertility of the substrates, which made nutrients available during the experiment (Table 2). Prato et al. (2020) highlighted that the inclusion of organic substrates in the soil promotes improvement in the chemical properties of the substrates mainly by increasing the availability of nutrients to the seedlings.

The increase in $\mathrm{P}$ in the substrates occurred according to the increase in DBB, obtaining an increase of $60.6 \%$ of $\mathrm{P}$ in the substrate with $100 \%$ DBB in relation to the soil (Table 2). Therefore, a greater amount of $P$ was available to be absorbed by the seedlings. $\mathrm{P}$ is an important nutrient in carbohydrate biosynthesis (Khavari-Nejad et al., 2009). This may be an indication to explain an improvement in the development of seedlings. Because in optimal conditions of $\mathrm{P}$, the number of carbohydrates produced is sufficient to meet the growing demand and, therefore, greater biomass production (Figure 2A), including an increase in the leaf area (Figure 2B) (Zambrosi et al., 2012). Consequently, plants with a larger leaf area can intercept greater light energy, converting it to chemical energy (Crous et al., 2015).

Table 3. Summary of analysis of variance for belowground dry mass (BDM), aboveground dry mass (ADM), leaf area (LA), root volume (RV), seedling height $(\mathrm{SH})$, diameter at neck height (lap) (DNH), root length (RL), emergency speed index (ESI), germination percentage (GP), and Dickson quality index (DQI).

\begin{tabular}{ccccccccccccc} 
VS & \multicolumn{10}{c}{ Medium Square } \\
\cline { 2 - 12 } & BDM & ADM & LA & RV & SH & DNH & RL & ESI & GP & DQI \\
DBB & $2.6^{*}$ & $1.7 \mathrm{~ns}$ & $20.4^{* *}$ & $2.1 \mathrm{~ns}$ & $4.8^{* *}$ & $5.4^{*}$ & $1.2 \mathrm{~ns}$ & $9.4^{* *}$ & $46.3^{* *}$ & $2.8^{*}$ \\
P value & 0.046 & 0.178 & $<0.001$ & 0.111 & $<0.001$ & 0.003 & 0.338 & 0.002 & 0.001 & 0.043 \\
CV (\%) & 28.53 & 26.3 & 20.14 & 22.88 & 13.93 & 12.36 & 15.85 & 14.33 & 6.63 & 25.18 \\
\hline
\end{tabular}

VS: Variation Source; CV: Coefficient of Variation. ${ }^{* *} \mathrm{~F}$ test significant at the $1 \%$ probability level, ${ }^{*}$ significant at the $5 \%$ probability level, ns: not significant $(\mathrm{N}=25)$. 
A

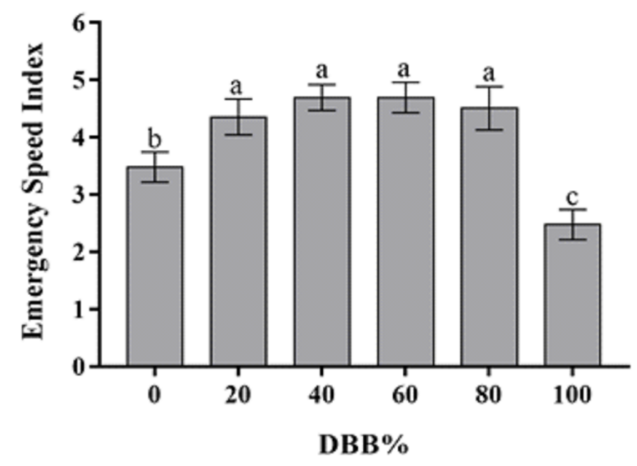

B

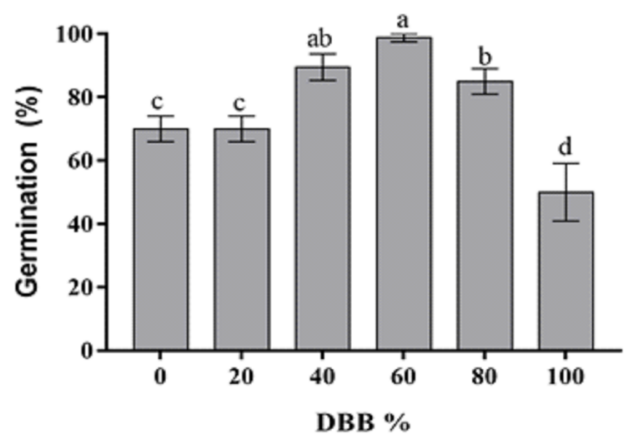

Figure 1. Mean values of emergency speed index (A) and germination percentage (B). Means followed by equal letters did not significantly differ according to a Tukey test at $5 \%$ significance. Bars indicate mean standard error.

A

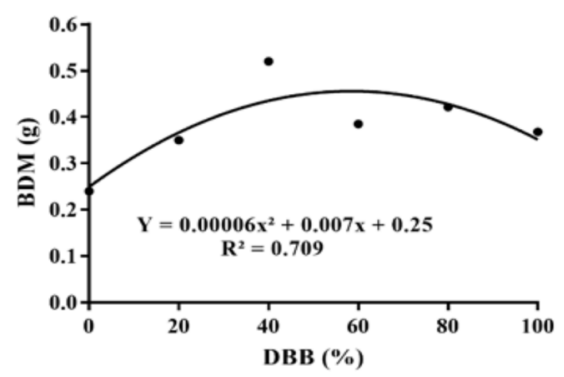

C

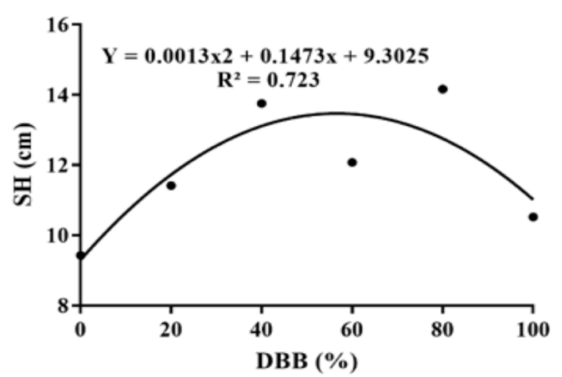

B

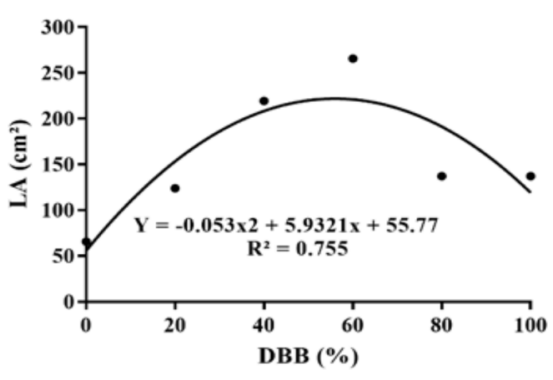

D

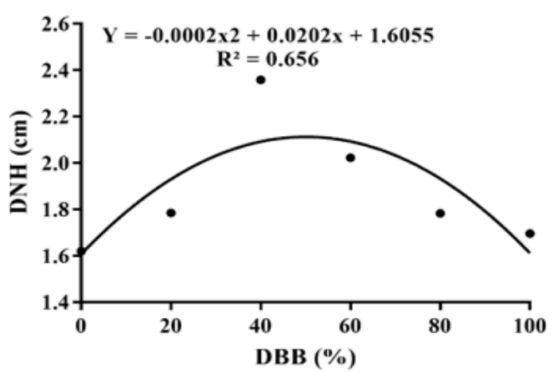

Figure 2. Regression diagrams among levels decomposed babassu biomass and belowground dry mass (A), leaf area (B), seedling height (C), diameter at neck height (lap) (D). 
In addition to this, it is observed that with the inclusion of DDB in the composition of the substrates, it caused an increase in the $\mathrm{N}$ content in the substrate by $89.3 \%$ (Table 2), which may have benefited the development of the plants. $\mathrm{N}$ is the macronutrient that maintains the photosynthetic rate at satisfactory levels, this is extremely important for seedling production (Kanai et al., 2008). In this study, the results suggest that an increase in the biometric variables $\mathrm{BDM}$ and LA with the inclusion of DDB, and consequently, a higher rate of production of photoassimilates, directed to the increase in plant height (Figure 2C) and stem diameter (Figure 2D).

However, after adding a substrate containing $\mathrm{C}$ in the soil, the microbial biomass is increased, as well as the demand for $\mathrm{N}$ by decomposer populations. According to Sigua et al., (2016), the inputs added to the soil with a C:N ratio greater than 24:1 can result in a temporary deficit of $\mathrm{N}$, that is, immobilization; this explains the results obtained with S6 (100\% DBB). This substrate had a C/N ratio greater than 24:1 (Table 2). Therefore, it is not ideal for the production of Jacaranda mimosifolia seedlings, which possibly requires the rapid availability of the nutrients, especially $\mathrm{N}$, as an effect of reducing biometric variables in cases of immobilization.

This phenomenon directly affects the photosynthetic capacity of seedlings, and when this occurs, the amount of photoassimilates produced is also affected, which is probably related to the increases observed in the other biometrics (Belapart et al., 2013). It is important to note that the higher the value of the seedling biomass, the stronger the seedling structure will be, as it will give the seedling greater resistance to adverse conditions in the field, promoting greater survival (Gonçalves et al., 2014).

Seedlings grown on substrates composed of 40 and $80 \%$ DBB showed excellent $\mathrm{SH}$ responses (Figure 2C). SH may be used as an estimate of the prediction of initial growth in the field (Gonçalves et al., 2014). Thus, it happened for DNH, which is, generally, observed in the evaluation of seedling survival capacity in the field (Silva et al., 2019). These results possibly occur due to the increase in the levels of nutrients that act in the growth and development of plants, playing a role in the physiological processes (Oosterhuis et al., 2013). As the $\mathrm{K}$ that promotes the firmness of the plant cell walls (turgor) as well as the nutrients $\mathrm{Ca}$ and $\mathrm{Mg}$, had their availability increased with the increase of DBB to the soil (Table 2).

An adequate supply of $\mathrm{K}$ available in the soil is necessary for optimal growth (Barzegar et al., 2020), especially for the thickening of the seedling stem (Valeri \& Corradini, 2005). Ca plays a role in the stability of biomembranes, with a fundamental role in cell division and development, cell wall structure, and formation of the middle lamella (Hepler \& Winship 2010). Mg acts in an indispensable for photosynthetic activity, since about a fifth of this plant tissue is found in chlorophyll molecules (Mauad et al., 2019).

However, it is supposed that from the dose of $80 \%$ of DBB, toxicity may have occurred and, consequently, the growth of these seedlings decreased (Silva et al., 2018). Additionally, $\mathrm{K}, \mathrm{Ca}$, and $\mathrm{Mg}$ compete for the same absorption sites on the membrane. Thus, the high availability of a certain element may cause a reduction in the absorption of the other (Taiz et al., 2017). Possibly, substrates composed of 40 to $80 \%$ DBB provide adequate and balanced nutrition among the nutrients for Jacaranda mimosifolia seedlings.

Applying DBB, better quality seedlings are produced. Using 20 to $100 \%$ DBB, increased DQI $(\mathrm{P}<0.05)$ compared to the control, but the $40 / 60$ relationship between soil and DBB provided seedlings with better DQI results (Figure 3). The quality of seedlings can determine success during the establishment of the forest stand (De Marco et al., 2020). The DQI produces a relationship between the morphological variables, suggesting higher values for higher quality seedlings (Prato et al., 2020). Such attributes were obtained in line with the DBB added to the soil, improving the physical and chemical characteristics of the substrates.

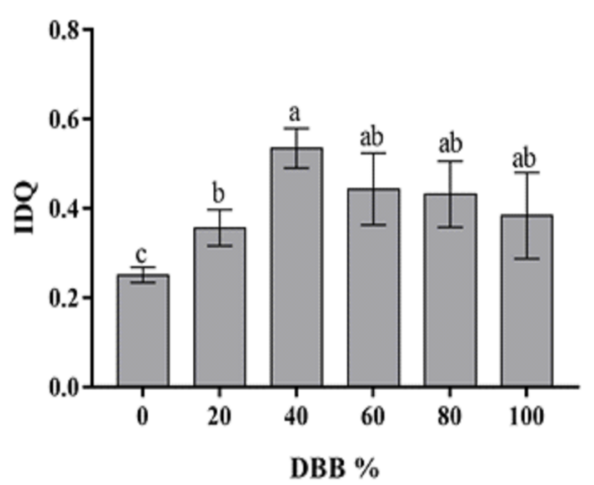

Figure 3. Mean values of the Dickson quality index for the Jacaranda mimosifolia seedlings. Means followed by equal letters did not significantly differ according to a Tukey test at 5\% significance. Bars indicate mean standard error.

Substrates composed of DBB, specifically the substrate with $40 \%$ DBB, improved seedling quality in relation to soil use. This is because, in a tropical climate, as in the study region, soil nutrients are limiting factors for plant growth due to acidic soil conditions and nutrient leaching (Fagbenro et al., 2015), so adding soil DBB is responsible for improvements in the availability of nutrients needed for the best germinative and biometric development of Jacaranda mimosifolia seedlings, contributing to obtain quality seedlings. 
The ADM presents a strong positive correlation with the $\mathrm{SH}$ of the seedlings $(\mathrm{r}=0.655)$, as verified by Araújo et al., (2017), possibly because it contributes more significantly to the biomass supply. Besides that, the ADM expresses a very strong positive correlation with the DQI $(r=0.998)$, and considering the variables used in the calculation, the correlation response indicates how the ADM is essential to improve the quality of the Jacaranda seedlings (Table 4).

Thus, like the ADM, SH also has a strong correlation $(r=0.656)$ with IQD, suggesting that better quality seedlings have better height development, which gives greater competitive advantage.

It is observed that LA has a strong positive correlation $(\mathrm{r}=0.614)$ with GP, while the latter has a strong positive correlation $(r=0.772)$ with ESI. This is congruent, since the more seeds germinate, the faster the germination speed of these seeds will be. And, similarly occurs with LA, because when seed germination occurs, initially the development of plants, including leaves, depends on the seed reserves.

Table 4. Pearson correlation matrix among belowground dry mass (BDM), aboveground dry mass (ADM), leaf area (LA), root volume (RV), seedling height $(\mathrm{SH})$, diameter at neck height (lap) (DNH), root length (RL), emergency speed index (ESI), germination percentage (GP), and Dickson quality index (DQI).

\begin{tabular}{|c|c|c|c|c|c|c|c|c|c|c|}
\hline & BDM & ADM & LA & RV & SH & DNH & RL & ESI & GP & DQI \\
\hline \multicolumn{11}{|l|}{$\mathrm{BDM}$} \\
\hline $\mathrm{ADM}$ & 0.494 & & & & & & \multicolumn{2}{|c|}{${ }^{1}$ Very strong } & & \\
\hline LA & 0.138 & 0.370 & & & & & \multicolumn{2}{|c|}{ Strong } & & \\
\hline RV & 0.042 & -0.029 & $0.558^{\star}$ & & & & \multicolumn{2}{|c|}{ Moderate } & & \\
\hline $\mathrm{SH}$ & $0.460^{*}$ & $0.655^{\star}$ & $0.454^{\star}$ & 0.297 & & & \multicolumn{2}{|c|}{ Weak } & & \\
\hline DNH & -0.143 & 0.215 & $0.516^{*}$ & 0.380 & 0.131 & & \multicolumn{2}{|c|}{ No correlation } & & \\
\hline $\mathrm{RL}$ & 0.123 & 0.233 & 0.130 & 0.107 & $0.446^{*}$ & 0.092 & & & & \\
\hline ESI & -0.135 & 0.224 & $0.491^{\star}$ & $0.522^{*}$ & $0.475^{\star}$ & $0.436^{*}$ & 0.209 & & & \\
\hline GP & -0.053 & 0.300 & $0.614^{*}$ & $0.444^{*}$ & $0.543^{*}$ & $0.453^{*}$ & 0.288 & $0.772^{\star}$ & & \\
\hline DQI & $0.511^{\star}$ & $0.998^{*}$ & 0.374 & -0.014 & $0.656^{*}$ & 0.227 & 0.236 & 0.275 & 0.312 & \\
\hline
\end{tabular}

${ }^{*}$ significant at 5\%. ${ }^{1}$ classified according to Gavioli et al. (2019), where $0<\mathrm{r} \leq 0.2$ : no correlation; $0.2<\mathrm{r} \leq 0.4$ : weak correlation; $0.4<\mathrm{r} \leq 0.6$ : moderate correlation; $0.6<\mathrm{r} \leq 0.8$ : strong correlation; and $0.8<\mathrm{r} \leq 1$ : very strong correlation.

\section{CONCLUSIONS}

The decomposed babassu biomass may be used as an alternative substrate for the production of Jacaranda mimosifolia seedlings. It is recommended to use $40 \%$ of the decomposed babassu biomass with $60 \%$ of soil in the substrate composition to improve the morphological development of the seedlings.

\section{SUBMISSION STATUS}

Received: 10 Jun. 2020

Accepted: 15 Oct. 2020

Associate editor: João Vicente de Figueiredo Latorraca

\section{CORRESPONDENCE TO}

\section{Hosana Aguiar Freitas de Andrade}

Universidade Federal do Ceará, Avenida Mister Hull, no s/n, CEP 60455-760, Fortaleza, CE, Brasil.

e-mail: hosana_f.andrade@hotmail.com

\section{REFERENCES}

Almeida BG, Donagemma GK, Ruiz HÁ, Braida JÁ, Viana JHM, Reichert JMM et al. Padronização de métodos para análise granulométrica no Brasil (Comunicado Técnico, 66). Rio de Janeiro: Embrapa; 2012.

Araújo EF, Aguiar AS, Arauco MAS, Gonçalves EO, Almeida KNS. Crescimento e qualidade de mudas de paricá produzidas em substratos à base de resíduos orgânicos. Nativa 2017; 5(1): 16-23. http://dx.doi.org/ 10.5935/2318-7670.v05n01a03

Barreto, Borba B, Hefler, Marisa S, Martinazzo, Garbin E et al. Germinação e crescimento inicial de Sesbania punicea (cav.) Benth: Influência de salinidade, inundação e luz. Revista Árvore 2018; 42(4): e420408. https://doi.org/10.1590/1806-90882018000400008.

Barzegar T, Mohammadi S, Ghahremani Z. Effect of nitrogen and potassium fertilizer on growth, yield and chemical composition of sweet fennel. Journal of Plant Nutrition 2020; 43(8): 1189-1204. http://dx.doi.org/10.1080/01904167.2020.1724306.

Berlapart D, Jeite SMM, Gigorotto MD, Pedrone LP. Efeito de diferentes doses de nitrogênio e cálcio no desenvolvimento inicial do guanandi. Unimar Ciências 2013; 22(12): 71- 77. 
Caldeira MVW, Delarmelina WM, Lübe SG, Gomes DR, Gonçalves EO, Alves AF. Biossólido na composição de substrato para a produção de mudas de Tectona grandis. Floresta 2012; 42(1): 77-84. http://dx.doi.org/10.5380/rf.v42i1.26302.

Crous KY, Òsvaldsson A, Ellsworth DS. Is phosphorus limiting in a mature Eucalyptus woodland? Phosphorus fertilisation stimulates stem growth. Plant and Soil 2015; 391(1): 293-305. http://dx.doi.org/10.1007 / s11104-015-2426-4.

Cruz CAF, Paiva HN, Gomes KCO, Guerrero CRA. Efeito de diferentes níveis de saturação por bases no desenvolvimento e qualidade de mudas de ipê-roxo (Tabebuia impetiginosa (Mart.) Standley). Scientia Forestalis 2004; (66): 100-7.

Dickson A, Leaf AL, Hosner JF. Quality appraisal of white spruce and white pine seedling stock in nurseries. Forestry Chronicle 1960; 36(1): 11-13. http://dx.doi.org/10.5558/tfc36010-1.

Di Rienzo JA, Casanoves F, Balzarini MG, Gonzalez L, Tablada M, Robledo CW. InfoStat versión 2020. Facultad de Ciencias Agropecuarias, Universidad Nacional de Córdoba, Argentina. [citado em 2020 abr. 16] Disponível em: http://www.infostat.com.ar.

Dionisio LFS, Auca EC, Bardales-Lozano RM, Schwartz G, Rodrigues RP, Corvera-Gomringer R. Production of Bertholletia excelsa Humb. \& Bonpl., (Lecythidaceae) seedlings in microenvironments under different substrates. Revista Brasileira de Ciências Agrárias 2019; 14(3): e5847. https://doi.org/10.34117/bjdv6n6-414.

Embrapa. Manual de métodos de análise de solos. 2rd ed. Embrapa: Rio de Janeiro; 1997.

Fagbenro JA, Oshunsanya SO, Oyeleye B. A. Effects of Gliricidia biochar and inorganic fertilizer on Moringa plant grown in an oxisol. Communications in Soil Science and Plant Analysis 2015; 46(5): 619-26. 10. https://doi.org/10.1080/00103624.2015.1005222.

Freitas ECS, Paiva HN, Leite HG, Neto SNO. Efeito da fertilização de fosfato e saturação base de substrato no crescimento e qualidade de mudas de Plathymenia foliolosa Benth. Revista Árvore 2017; 41(1): e410111. http://dx.doi.org/10.1590/1806-90882017000100011.

Gonçalves EO, Petri GM, Caldeira MVW, Dalmaso TT, Silva AG. Crescimento de mudas de Ateleia glazioviana em substratos contendo diferentes materiais orgânicos. Floresta e Ambiente 2014; 21(3): 339-348. http://dx.doi.org/10.1590/2179-8087.029213.

Gonçalves EP, França PRC, Viana JS, Alves EU, Guedes RS, CR. Umedecimento do substrato e temperatura na germinação de sementes de Parkia platycephala Benth. Ciência Florestal 2015; 25(3): 563-569. http://dx.doi.org/10.5902/1980509819607.

Han AR, Kim HJ, Jung JB, Park PS. Seed germination and initial seedling survival of the subalpine tree species, Picea jezoensis, on different forest floor substrates under elevated temperature. Forest Ecology and Management 2018; 429: 579-588. http://dx.doi.org/10.1016/j.foreco.2018.07.042.

Hepler PK \& Winship JL. Calcium at the cell wall-cytoplast interface. Journal of Integrative Plant Biology 2010; 52(2): 147-60. http://dx.doi.org/10.1111/j.1744-7909.2010.00923.x.

Kanai S, Adu-Gymfi J, Lei K, Ito J, Ohkura K, Moghaieb REA, El-Shemy $\mathrm{H}$ et al. N-deficiency damps out circadian rhythmic changes of stem diameter dynamics in tomato plant. Plant Science 2008; 174(2): 183-191. http://dx.doi.org/10.1016/j.plantsci.2007.11.006.
Khavari-Nejad RA, Najafi F, Tofighi C. Diverse responses of tomato to $\mathrm{N}$ and $\mathrm{P}$ deficiency. International Journal of Agriculture and Biology 2009; 11(2): 209-213.

Lima Filho P, Leles PSS, Abreu AHM, Silva EV, Fonseca AC. Produção de mudas de Ceiba speciosa em diferentes volumes de tubetes utilizando o biossólido como substrato. Ciência Florestal 2019; 29(1): 27-39. https://doi.org/10.5902/1980509819340.

Mapa. Instituição normativa. DAS no 17, de 21 de maio de 2007. Diário Oficial da República Federativa do Brasil. Brasília, 24 de maio de 2007, seção 1, p. 8.

De Marco R; Silva RF, Da Ros CO, Viel P. Initial growth and quality of Toona ciliata seedlings under different substrates. Floresta e Ambiente 2020; 27(3): e20180273. https://doi.org/10.1590/2179-8087.027318

Martins CC, Bombonato J, Marcussi F, Martins D. Effects of substratum, temperature, and treatments to overcome dormancy on the germination of Fimbristylis dichotoma seeds. Revista de Ciências Agrárias 2013; 56: 44-48. http://dx.doi.org/10.4322/rca.2013.079.

Mauad M, Santana RS, Silva HHM, Altomar PH, Silva RMMF, Vitorino ACT. Macronutrient deficiency and anatomic modifications in crambe leaves. Journal of Plant Nutrition 2019. 42(18): 2363-2372. http://dx.doi.org/10.1080/01904167.2019.1659331.

Moharram FA, Marzouk MSA. A novel phenylethanoid dimer and flavonoids from Jacaranda mimosaefolia. Zeitschrift fur Naturforschung B 2007; 62: 1213-1220. http://dx.doi.org/10.1515/ znb-2007-0918.

Oliveira, Morbeck AK, Souza, Alves S, Souza, Santos J et al. Temperature and substrate influences on seed germination and seedling formation in Callisthene fasciculata mart. (Vochysiaceae) in the laboratory. Revista Árvore 2015; 39(3): 487-495. http://dx.org/10.1590/0100-67622015000300009.

Oosterhuis DM, Loka DA, Raper TB. Potassium and stress alleviation: Physiological functions and management of cotton. Journal of Plant Nutrition and Soil Science 2013; 176(3): 331-343. http://dx.doi.org/10.1002/jpln.201200414.

Passos MLV, Zambrzycki GC, Pereira RS. Balanço hídrico e classificação climática para uma determinada região de ChapadinhaMA. Revista Brasileira de Agricultura Irrigada 2016; 10(4): 758-766. http://dx.doi.org/10.7127/rbai.v10n400402.

Prato AI, Sánchez SN, Zuluaga JJ, Souza PVD. Substrates, seedling age and environment in the initial growth of Cariniana pyriformis Miers. Floresta 2020; 50(2): 1287-1296. http://dx.doi.org/10.5380/ rf.v50 i2. 62666.

Santos HG, Jacomine PKT, Anjos LHC, Oliveira VA, Lumbreras JF, Coelho MR et al. Sistema brasileiro de classificação de solos. 3rd ed. Rio de Janeiro: EMBRAPA; 2013.

Sigua GC, Novak JM, Watts DW, Szogi AA, Shumaker PD. Impact of switchgrass biochars with supplemental nitrogen on carbonnitrogen mineralization in highly weathered Coastal Plain Ultisols. Chemosphere 2016; 145: 135-141. http://dx.doi.org/10.1016/ j.chemosphere.2015.11.063.

Silva FAM, Nunes GM, Zanon JG, Bôas RLV, Silva RB. Granulated and biosolid fertilizers on the quality of Schinus terebinthifolius Raddi seedlings. Floresta e ambiente 2019; 26(3): e20171104. http://dx.doi.org/10.1590/2179-8087.110417. 
Silva RS, Furtado MB, Machado NAF, Andrade HAF, Oliveira ARF, Farias MF et al. Effect of Boron (B) and lime on production of watermelon in dystrophic yellow latosol soil. Australian Journal of Crop Science 2018; 2(12): 1975-1982. http://dx.doi.org/10.21475/ajcs.18.12.12.p1405.

Silva-Matos RRS, Silva GB, Marques AS, Monteiro ML, Cavalcante ÍHL, Osajima JA. New organic substrates and boron fertilizing for production of yellow passion fruit seedlings. Archives of Agronomy and Soil Science 2015; 62(3): 445-455. http://dx.doi.org/10.1080/ 03650340.2015 .1050000 .

Soares CB, Freitas ECS, Paiva HN, Neves JCL. Fontes e doses de nitrogênio no crescimento e qualidade de mudas de Cassia grandis e Peltophorum dubium L. Revista Árvore 2017; 41(2) e410214. http://dx.doi.org/10.1590/1806-90882017000200014.

Socolowski F, Takaki M. Germination of Jacaranda mimosifolia (D. Don -Bignoniaceae) seeds: effects of light, temperature and water stress. Brazilian Archives of Biology and Technology 2004; 47(5): 785-792. http://dx.doi.org/10.1590/ S1516-89132004000500014.
Trazzi PA, Caldeira MVW, Passos RR, Gonçalves EO. Substratos de origem orgânica para produção de mudas de teca (Tectona grandis Linn. F.). Ciência Florestal 2013; 23(3): 401-409. http://dx.doi.org/10.5902/1980509810551.

Taiz L, Zeiger E, Moller IM, Murphy A. Fisiologia e desenvolvimento vegetal. 6th ed. Porto Alegre: Artmed; 2017.

Valeri SV, Corradini L. Fertilização em viveiros para a produção de mudas de Eucalyptus e Pinus. In: Gonçalves JLM, Benedetti V, editor. Nutrição e fertilização florestal. Piracicaba: Instituto de Pesquisas e Estudos Florestais; 2005.

Zaghloul A, Gohar A, Ahmad M, Baraka H, El-Bassuony A. Phenylpropanoids from the stem bark of Jacaranda mimosaefolia. Natural Product Research 2011; 25(1): 68-76. http://dx.doi.org/ 10.1080/14786419.2010.511217.

Zambrosi FCB, Mattos JRD, Furlani PR, Quaggio JA, Boaretto RM. Eficiência de Absorção e Utilização de Fósforo em Porta Enxertos Cítricos. Revista Brasileira de Ciência do Solo 2012: 36(2): 485-496. 